\title{
NITROGEN FIXATION ACTIVITY, EMISSION OF N2O AND CO2 IN PEA AGROCOENOSES UNDER THE INLFUENCE OF FERTILIZERS AND PRE-SOWING SEEDS BACTERIZATION
}

Volkogon V.V., Zhurba M.A.

Institute of Agricultural Microbiology and Agricultural Production NAAS

97, Shevchenko str., Chernihiv, 14027, Ukraine

E-mail: zhurba-m2013@yandex.ua

The dynamics of nitrogen fixation, emissions of $\mathrm{N}_{2} \mathrm{O}$ and $\mathrm{CO}_{2}$ in pea agrocoenoses under the influence of different fertilization systems and pre-sowing seeds inoculation with microbial preparation Rhizohumin were studied in stationary field experiment on leached black soil (short crop rotation potatoes - spring barley - peas - winter wheat). It was observed that symbiotic nitrogen fixation process had become active on the second year aftereffect of 40 t/ha of cattle manure, green manure and use of low $\left(N_{30} P_{30} K_{30}\right)$ and medium $\left(N_{60} P_{60} K_{60}\right)$ doses of mineral fertilizers. Rhizohumin had significantly increase nitrogen fixation activity in all variants except of the one with manure. Increase of $\mathrm{N}_{2} \mathrm{O}$ emissions had corresponded to the increasing doses of mineral fertilizers. The use of biological preparation had ensured the reduction of gaseous nitrogen losses due to the initiation of plants development. Carbon dioxide emission values had depended on the type and dose of fertilizers. Rhizohumin had reduced the emission of gaseous carbon compounds in variants with different fertilizer backgrounds due to its extensive use in the formation of additional yield.

Keywords: peas, symbiotic nitrogen fixation, $\mathrm{N}_{2} \mathrm{O}$ emission, $\mathrm{CO}_{2}$ emission, fertilizers.

Prerequisites to take into the account the activity of different biological processes in soils of agrocenoses is dictated by modern concepts of the impact of technological factors not only on the production process of agricultural crops, but also on the environment. One of the most accurate tests of the soil-microorganisms-plants level reaction on agrochemical load is nitrogen fixation activity [1]. Emissions of greenhouse gases (especially $\mathrm{N}_{2} \mathrm{O}$ and $\mathrm{CO}_{2}$ ) are equally important diagnostic indicators of the state of agrocoenoses.

Gaseous losses of nitrogen fertilizers are primarily associated with the processes nitrification and denitrification processes occurring in the soil with microorganisms. Aggregated data from 80 field experiments indicates that nitrogen losses in the form of its oxides comprises in average $26 \%$ of the total nitrogen applied. Higher losses were observed in the fields with higher doses of fertilizers used. This indicates the necessity to consider the peculiarities of the biological transformation of nitrogen in agrocoenoses at establishing crops fertilization principles [2-3]. 
Recently, more attention is paid to the study of carbon changes in ecosystems associated with both global changes in carbon dioxide in the atmosphere and with the need in additional $\mathrm{CO}_{2}$ to the metabolic processes of cultivated plants in order to improve their performance.

Thus, the purpose of our research was to determine the intensity of the processes of symbiotic fixation of atmospheric nitrogen, $\mathrm{N}_{2} \mathrm{O}$ and $\mathrm{CO}_{2}$ emissions at peas growing on different fertilization backgrounds.

Materials and methods. The experiments were performed during the 2012-2013 in a stationary field experiments in the Institute of Agricultural Microbiology and Agricultural Production NAAS on leached black soils $\left(\mathrm{pH}_{\text {salt }}-5.2\right.$, humus $-3.01 \%$, readily hydrolyzed nitrogen $-109 \mathrm{mg} / \mathrm{kg}$ soil, mobile compounds of phosphorus $\left(\mathrm{P}_{2} \mathrm{O}_{5}\right)-168 \mathrm{mg} / \mathrm{kg}$ soil (by Kirsanov), exchangeable potassium $\left(\mathrm{K}_{2} \mathrm{O}\right)-$ $58 \mathrm{mg} / \mathrm{kg}$ soil (by Kirsanov).

Experiment crop rotation was as following - potatoes, spring barley, peas and winter wheat. Experiments replication - four fold. Plots location - randomized. Plots accounting area $50 \mathrm{~m}^{2}$.

The second year aftereffect of $40 \mathrm{t} / \mathrm{ha}$ manure (applied under potatoes) was studied. Fertilizers were applied in doses $\mathrm{N}_{30} \mathrm{P}_{30} \mathrm{~K}_{30}, \mathrm{~N}_{60} \mathrm{P}_{60} \mathrm{~K}_{60}$ and $\mathrm{N}_{90} \mathrm{P}_{90} \mathrm{~K}_{90}$. Organic and mineral fertilization systems had stipulated the second year aftereffect of manure in combination with the direct effect of fertilizers applied in low doses $\left(\mathrm{N}_{30} \mathrm{P}_{30} \mathrm{~K}_{30}\right)$. For green manure the oil radish was grown as an intermediate crop. Plant residues were put into the soil in spring by shallow $(10 \mathrm{~cm})$ plowing.

Peas of Deviz variety were grown in two experimental blocks - with and without pre-sowing seed inoculation with biological preparation Rhizohumin, included an active rhizobia strain and physiologically active substances of biological origin (TU U 24.1-00497360-003:2007). As it was established previously the use of biological preparation increases field germination and seeds vigor, promotes developed of root system and active legume-rhizobial symbiosis [4].

Symbiotic nitrogen fixation activity was determined in a dynamics with chamber method using the acetylene test [5]. Ethylene content in the samples was determined on a gas chromatograph "Chrom-4" with a flame ionization detector. Thermostat temperature $40{ }^{\circ} \mathrm{C}$; gas flow: hydrogen $-15 \mathrm{~cm}^{3} / \mathrm{min}$, nitrogen $-100 \mathrm{~cm}^{3} / \mathrm{min}$, air $-500 \mathrm{~cm}^{3} / \mathrm{min}$. Sorption steel column $3 \mathrm{~m}$ filled with Parapak Q 60-80 mesh sorbent was used.

To evaluate the emissions of carbon dioxide and nitrous oxide in the "soil - plant" system the closed chamber method with our modification was used [6, 7]. Direct $\mathrm{N}_{2} \mathrm{O}$ emissions were observed by gas chromatography "Tsvet-500 M" with electron capture detector. Column temperature $40{ }^{\circ} \mathrm{C}$, temperature of evaporator $120{ }^{\circ} \mathrm{C}$, temperature of detector $330{ }^{\circ} \mathrm{C}$. Gas consumption - medium (argon and methane 95/5) $-35 \mathrm{~cm}^{3} / \mathrm{min}$. Sorption steel column $3 \mathrm{~m}$ filled with Parapak Q 60-80 mesh sorbent was used. 
$\mathrm{CO}_{2}$ concentration was detected on gas chromatograph was determined "Tsvet-500 M" with thermal conductivity detector (bridge current $130 \mathrm{~mA}$ ). Column temperature $25{ }^{\circ} \mathrm{C}$, detector temperature $40{ }^{\circ} \mathrm{C}$. Consumption of carrier gas (helium) $-20 \mathrm{~cm}^{3} / \min$ [8]. Sorption steel columns were filled with sorbent Parapak Q 60-80 mesh.

Peas yield and statistical analysis of the results was carried out by standard techniques [9].

Results and discussion. Determination of the dynamics of nitrogen fixation activity demonstrates the significant stimulation of process during the budding phase in variants with low and medium doses of fertilizers with pre-sowing seed bacterization with Rhizohumin (Fig. 1). The later observations had shown the same trends. The high dose of fertilizers over a long period of time inhibits the functional expression of the symbiotic apparatus of pea plants and stimulates the activity of symbiotic nitrogen fixation only at the end of the growing season. The aftereffect of manure on the second year generally intensifies the course of the nitrogen fixation, but eliminates the positive impact of pre-inoculation. Organic and mineral fertilization had reduced nitrogen fixation activity. Green manure had a positive effect on the activity of symbiotic nitrogen fixation, starting from the flowering stage of pea plants in both varinats with ad without pre-sowing seeds inoculation with Rhizohumin.

Determination of the emission of nitrous oxide characteristics in the dynamic indicates a significant loss of gaseous nitrogen in the variants with the second year aftereffect of manure and variants with the second year aftereffect of manure $+\mathrm{N}_{30} \mathrm{P}_{30} \mathrm{~K}_{30}$ (Fig. 2). Rhizohumin in these variants has almost no effect on the process. In variants with mineral crop fertilization $\mathrm{N}_{2} \mathrm{O}$ emission had increased along with the increasing doses of fertilizers. Minimal losses at this we observed in the variants with $\mathrm{N}_{30} \mathrm{P}_{30} \mathrm{~K}_{30}$. It should be noted that in variants with high dose of fertilizers $\mathrm{N}_{90} \mathrm{P}_{90} \mathrm{~K}_{90}$ the reduction of losses of gaseous nitrogen compounds were observed under the use of biological preparation. In our opinion the impact of microbial preparation on reduction of losses of gaseous nitrogen is occurred due the improvement of symbiotic properties of legume-rhizobial system (see Fig. 1) and the formation of additional yield (see below). Green manure had not influenced the increase of nitrous oxide emissions as compared with a control variant pea growing technology.

Average readings of nitrogen losses due to the $\mathrm{N}_{2} \mathrm{O}$ emissions are given in Table 1. The highest losses had occur at aftereffect of $40 \mathrm{t} / \mathrm{ha}$ manure and in the variant with organic and mineral fertilization. The lowest values were observed on green manure background. Application of Rhizohumin had reduced the total losses in the variant without the fertilizers, with fertilization and green manure background. 
$\square$ Without inoculation $\square$ Rhizohumin

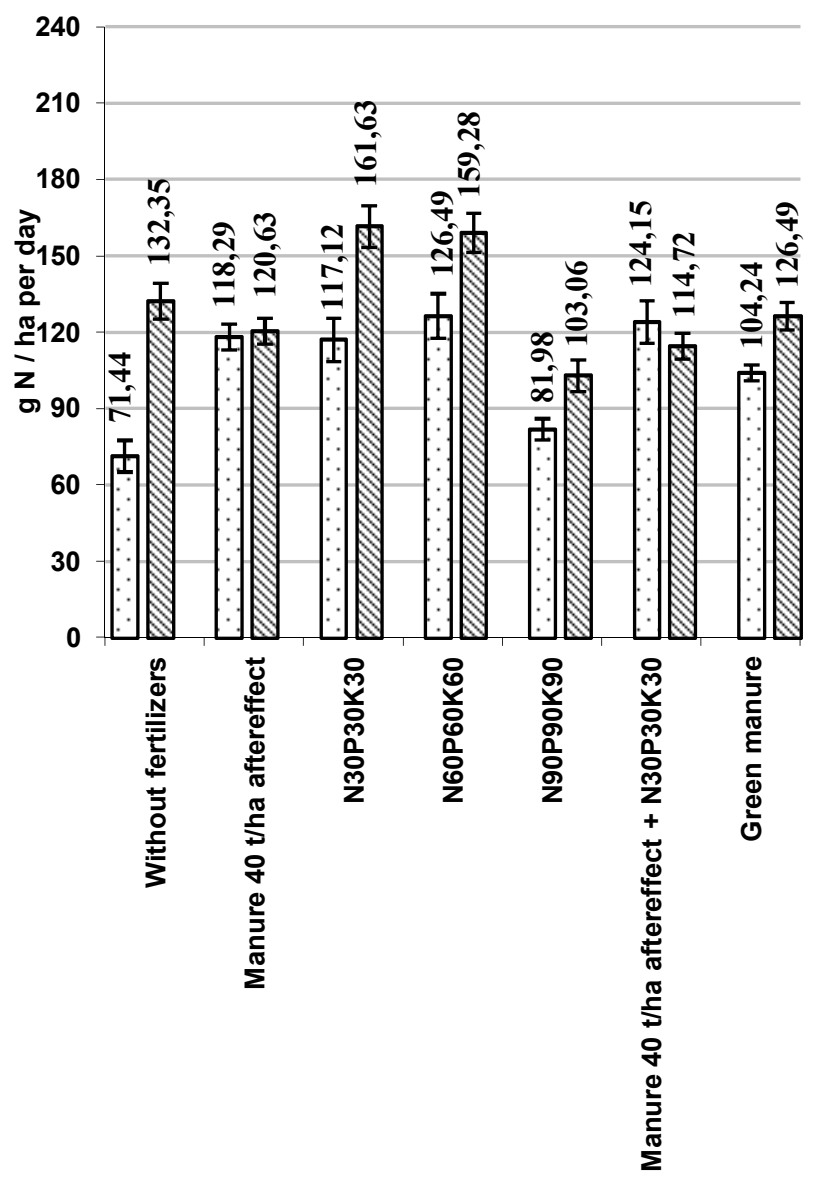

Budding stage

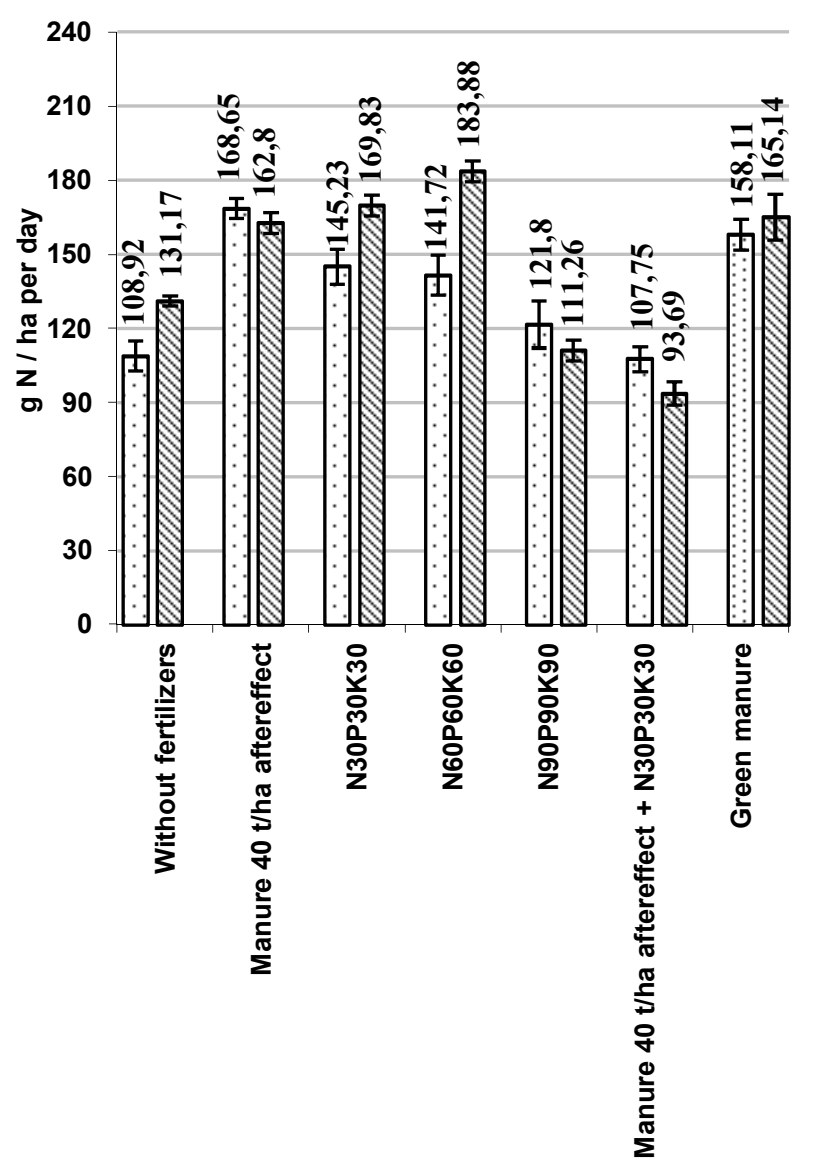

Flowering stage

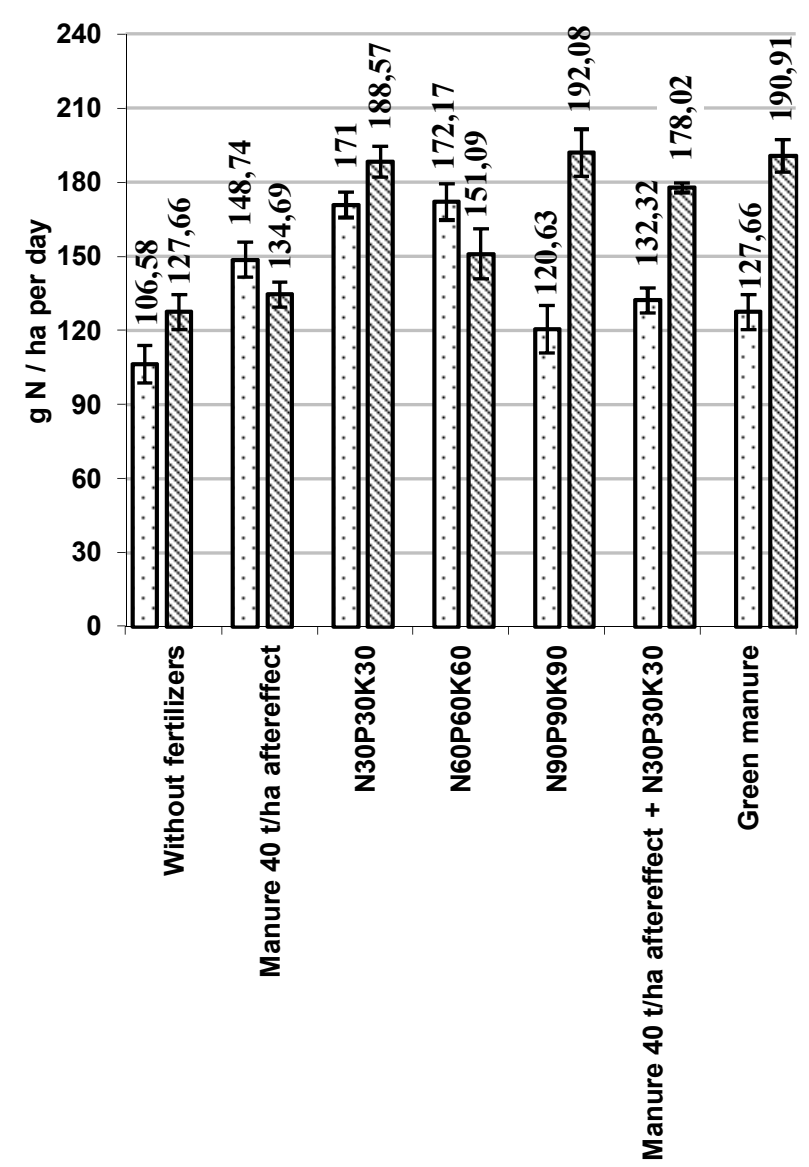

Pod formation stage

Fig. 1. Nitrogen fixation dynamics in "Soil-Pea Plant" system under the influence of fertilizers and Rhizohumin 


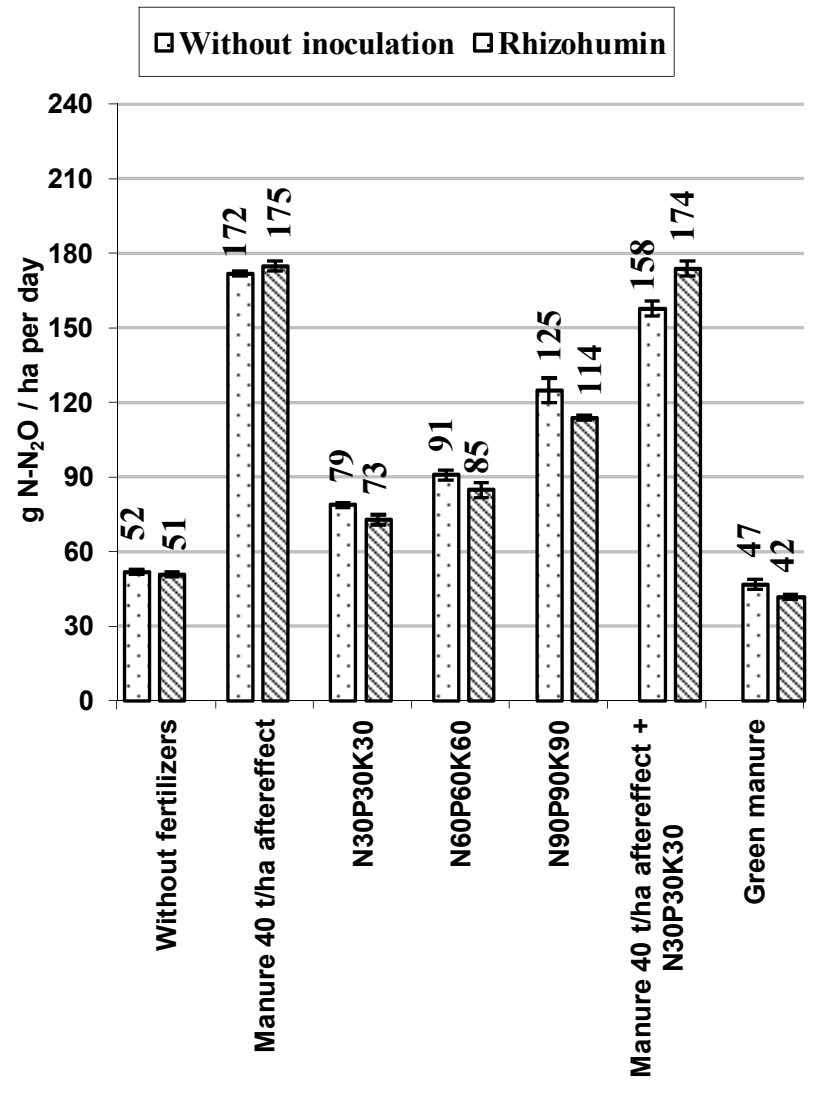

Budding stage

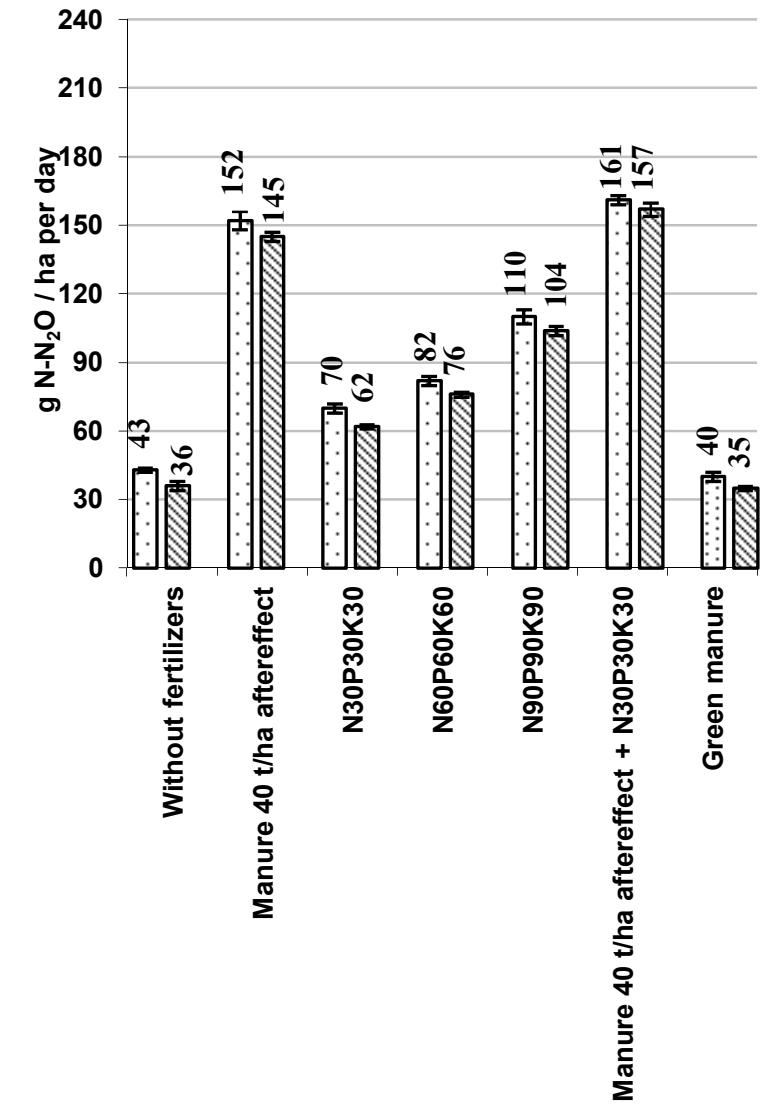

Flowering stage

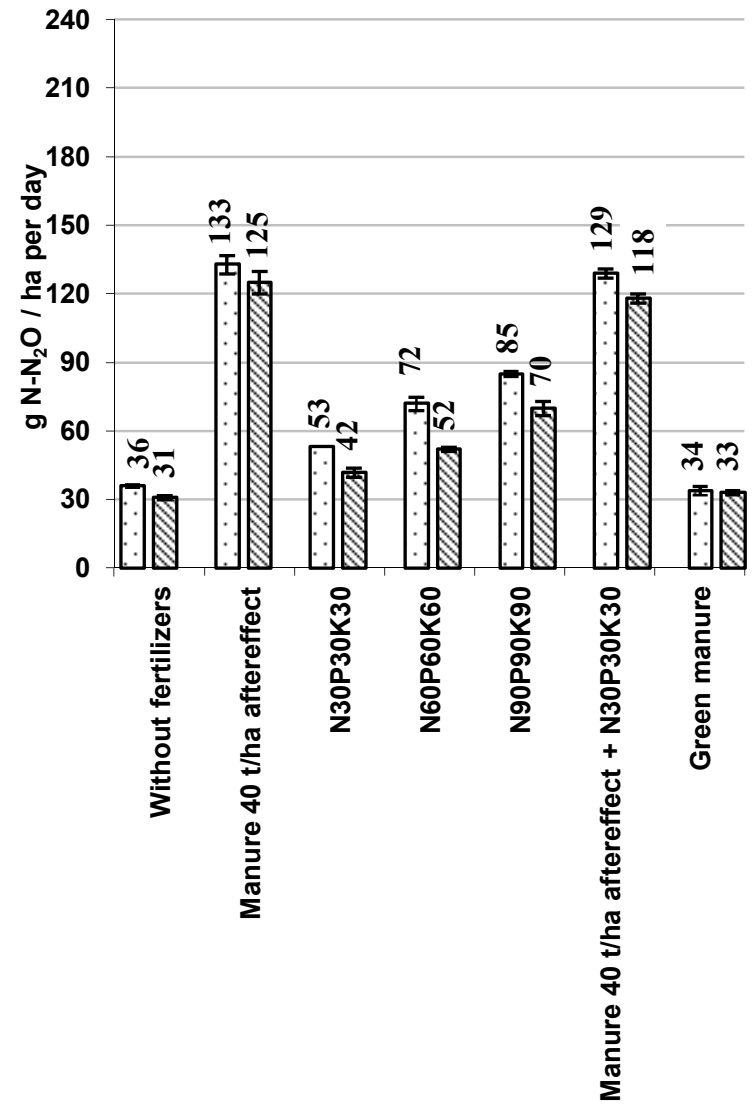

Pod formation stage

Fig. 2. Emission of $\mathrm{N}_{2} \mathrm{O}$ from the soil under pea plants in dynamics under the influence of fertilizers and Rhizohumin (2013) 


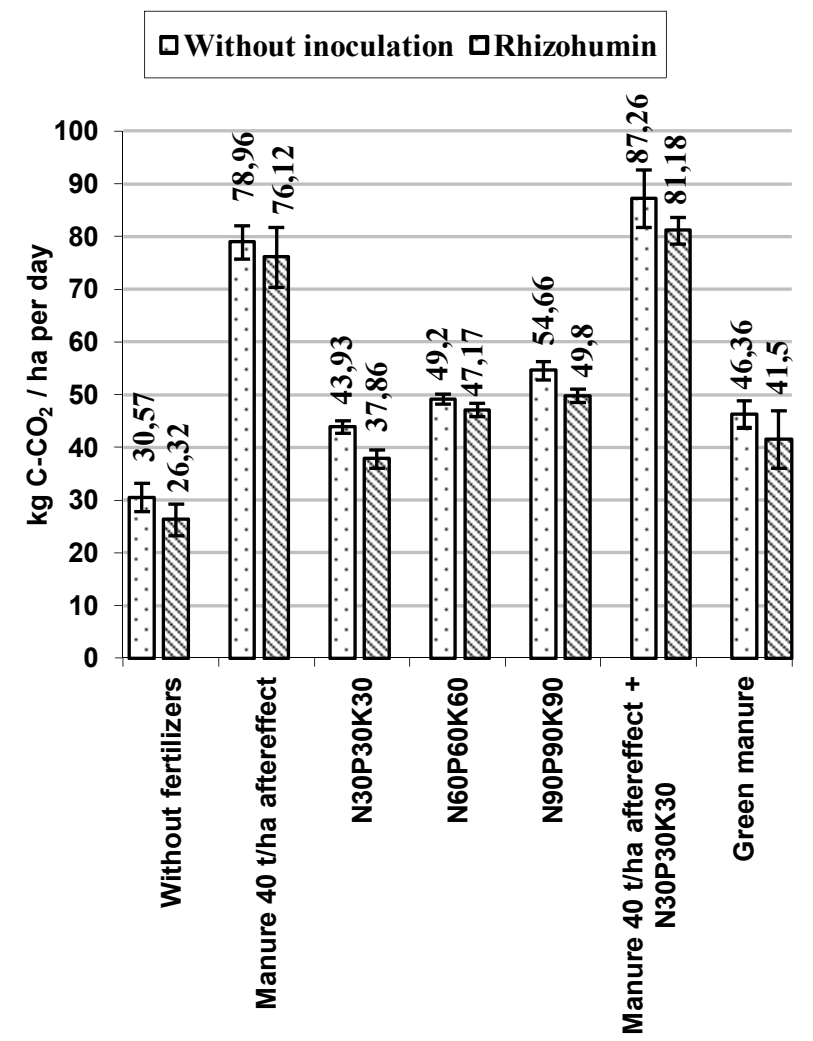

Budding stage

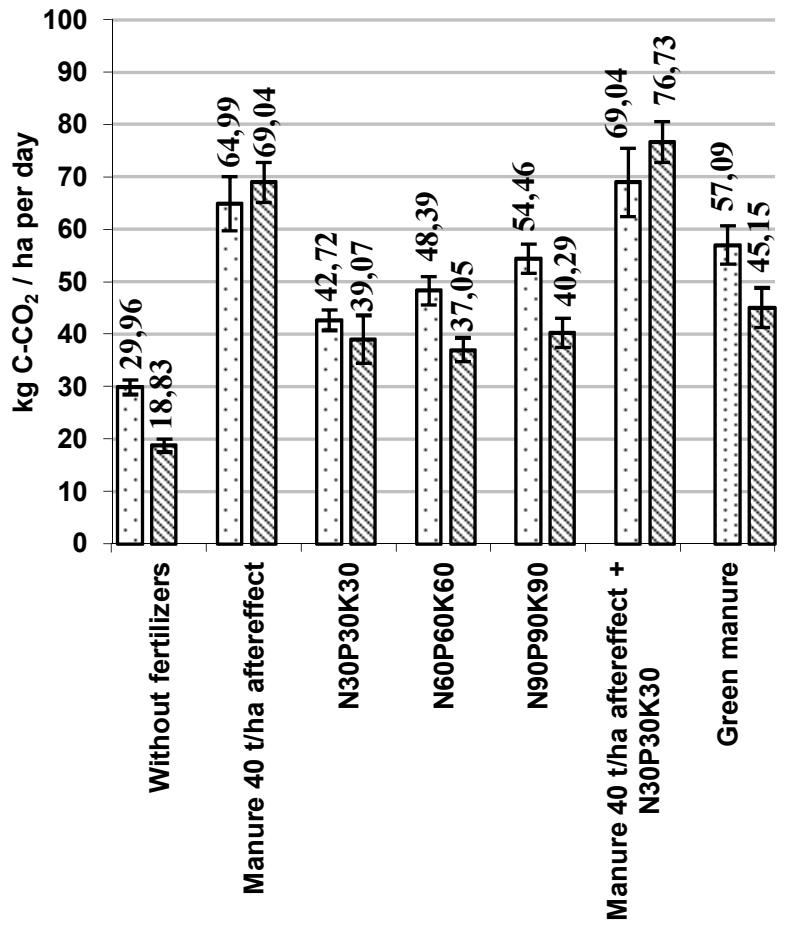

Flowering stage

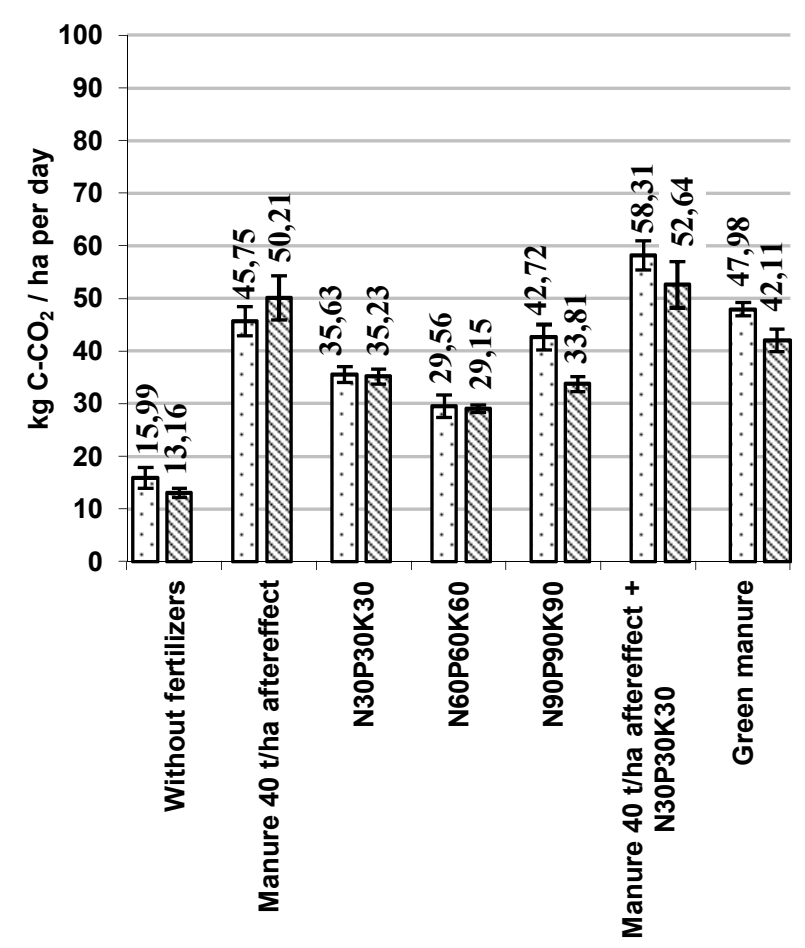

Pod formation stage

Fig. 2. Emission of $\mathrm{CO}_{2}$ from the soil under pea plants in dynamics under the influence of fertilizers and Rhizohumin (2013) 
Table 1. Total emission of $\mathrm{N}-\mathrm{N}_{2} \mathrm{O}$ during the growing season of pea plants under the influence of fertilizers and inoculation (2013)

\begin{tabular}{|l|c|c|}
\hline \multirow{2}{*}{ Variants } & \multicolumn{2}{|c|}{ Emission of $\mathrm{N}^{*} \mathrm{~N}_{2} \mathrm{O}, \mathrm{kg} / \mathrm{ha}$} \\
\cline { 2 - 3 } & Without inoculation & With inoculation \\
\hline Control, without fertilizers & 3,93 & 3,54 \\
\hline Manure 40 t/ha (aftereffect) & 13,71 & 13,35 \\
\hline $\mathrm{N}_{30} \mathrm{P}_{30} \mathrm{~K}_{30}$ & 6,06 & 5,31 \\
\hline $\mathrm{N}_{60} \mathrm{P}_{60} \mathrm{~K}_{60}$ & 7,35 & 6,39 \\
\hline $\mathrm{N}_{90} \mathrm{P}_{90} \mathrm{~K}_{90}$ & 9,6 & 8,64 \\
\hline $\begin{array}{l}\text { Manure } 40 \text { t/ha (aftereffect) } \\
+\mathrm{N}_{30} \mathrm{P}_{30} \mathrm{~K}_{30}\end{array}$ & 13,44 & 13,47 \\
\hline Green manure & 3,63 & 3,30 \\
\hline
\end{tabular}

Study of $\mathrm{CO}_{2}$ emissions from the soil under pea plants in dynamics (Fig. 3) had shown the dependence of process activity on the crop fertilization type. The high level of carbon dioxide emissions in variants with $40 \mathrm{t} / \mathrm{ha}$ manure (aftereffect) and $40 \mathrm{t} / \mathrm{ha}$ manure (aftereffect) $+\mathrm{N}_{30} \mathrm{P}_{30} \mathrm{~K}_{30}$. This could be due both to the large number of cellulose brought with manure during previous years, and with the activation of microbiological activity due to income of a large number of microorganisms, as was indicated at the end of the nineteenth century by V. V. Dokuchaev [10]. The intensity of the soil "breathing" was also high in the variants with green manure, due to the presence of large number of fresh organic matter. Emissions of carbon dioxide were higher together with the increasing doses of mineral fertilizers. At this application of Rhizohumin promotes reduction of $\mathrm{CO}_{2}$ emissions. We believe that this reduction can be explained by optimization of plants nitrogen nutrition and the involvement of additional quantities of carbon for structural needs of the plant organism.

The aggregated values of $\mathrm{CO}_{2}$ losses are presented in Table 2. Rhizohumin had reduced the emission of carbon dioxide in variants with mineral fertilizers and, in some extents, with organic-mineral fertilizers, as well as green manure. In variant with second year aftereffect of $40 \mathrm{t} / \mathrm{ha}$ of manure the inoculation had caused the increase of carbon dioxide emissions.

Observed peculiarities of nitrogen fixation processes, $\mathrm{N}_{2} \mathrm{O}$ and $\mathrm{CO}_{2}$ emissions were generally similar in both experimental years, although were different in absolute values.

Calculation of pea yield in 2012 and 2013 had shown that the crop productivity had increased along with the increasing doses of fertilizers, although the impact of each extra dose of fertilizer on the crop productivity in the experiment was reduced. The aftereffect of manure on the second year had ensured one of the lowest in the experiment increase of pea productivity, but nevertheless it was statistically significant. The use of green manure also contributes to the performance of peas, but with the lowest values throughout the experiment (Table 3). 
Table 2. Total emission of $\mathrm{CO}_{2}$ for the growing season of pea plants under the influence of fertilizers and inoculation (2013)

\begin{tabular}{|l|c|c|}
\hline \multirow{2}{*}{ Variants } & \multicolumn{2}{|c|}{ Emission of $\mathrm{C}^{*} \mathrm{CO}_{2}, \mathrm{t} / \mathrm{ha}$} \\
\cline { 2 - 3 } & Without inoculation & With inoculation \\
\hline Control, without fertilizers & 6,88 & 5,20 \\
\hline Manure 40 t/ha (aftereffect) & 17,07 & 17,58 \\
\hline $\mathrm{N}_{30} \mathrm{P}_{30} \mathrm{~K}_{30}$ & 11,00 & 10,09 \\
\hline $\mathrm{N}_{60} \mathrm{P}_{60} \mathrm{~K}_{60}$ & 11,44 & 10,20 \\
\hline $\mathrm{N}_{90} \mathrm{P}_{90} \mathrm{~K}_{90}$ & 13,66 & 11,15 \\
\hline $\begin{array}{l}\text { Manure } 40 \text { t/ha (aftereffect) } \\
+\mathrm{N}_{30} \mathrm{P}_{30} \mathrm{~K}_{30}\end{array}$ & 19,38 & 18,94 \\
\hline Green manure & 13,62 & 11,58 \\
\hline
\end{tabular}

Table 3. Influence of bacterization and fertilizers on yield of pea plants of Deviz variety (2013)

\begin{tabular}{|c|c|c|c|c|c|}
\hline \multirow{3}{*}{ Variants } & \multirow{3}{*}{ Yield, t/ha } & \multicolumn{4}{|c|}{ Increase } \\
\hline & & \multicolumn{2}{|c|}{ from fertilizers } & \multicolumn{2}{|c|}{ from inoculation } \\
\hline & & $\mathrm{t} / \mathrm{ha}$ & $\%$ & $\mathrm{t} / \mathrm{ha}$ & $\%$ \\
\hline \multicolumn{6}{|c|}{ Without inoculation } \\
\hline Control, without fertilizers & 1,99 & - & - & - & - \\
\hline $\begin{array}{l}\text { Manure } 40 \mathrm{t} / \mathrm{ha} \\
\text { (aftereffect) }\end{array}$ & 2,29 & 0,30 & 15,1 & - & - \\
\hline $\mathrm{N}_{30} \mathrm{P}_{30} \mathrm{~K}_{30}$ & 2,82 & 0,83 & 41,7 & - & - \\
\hline $\mathrm{N}_{60} \mathrm{P}_{60} \mathrm{~K}_{60}$ & 3,15 & 1,16 & 58,3 & - & - \\
\hline $\mathrm{N}_{90} \mathrm{P}_{90} \mathrm{~K}_{90}$ & 3,35 & 1,36 & 68,3 & - & - \\
\hline $\begin{array}{l}\text { Manure } 40 \mathrm{t} / \mathrm{ha} \\
\text { (aftereffect) }+\mathrm{N}_{30} \mathrm{P}_{30} \mathrm{~K}_{30}\end{array}$ & 2,76 & 0,77 & 38,7 & - & - \\
\hline Green manure & 2,24 & 0,25 & 12,6 & - & - \\
\hline \multicolumn{6}{|c|}{ Inoculation with Rhizohumin } \\
\hline Control, without fertilizers & 2,30 & - & - & 0,31 & 15,6 \\
\hline $\begin{array}{l}\text { Manure } 40 \mathrm{t} / \mathrm{ha} \\
\text { (aftereffect) }\end{array}$ & 2,51 & 0,52 & 26,1 & 0,22 & 9,6 \\
\hline $\mathrm{N}_{30} \mathrm{P}_{30} \mathrm{~K}_{30}$ & 3,33 & 1,34 & 67,3 & 0,51 & 18,1 \\
\hline $\mathrm{N}_{60} \mathrm{P}_{60} \mathrm{~K}_{60}$ & 3,50 & 1,51 & 75,9 & 0,35 & 11,1 \\
\hline $\mathrm{N}_{90} \mathrm{P}_{90} \mathrm{~K}_{90}$ & 3,62 & 1,66 & 83,4 & 0,27 & 8,1 \\
\hline $\begin{array}{l}\text { Manure } 40 \mathrm{t} / \mathrm{ha} \\
\left(\text { aftereffect) }+\mathrm{N}_{30} \mathrm{P}_{30} \mathrm{~K}_{30}\right.\end{array}$ & 3,05 & 1,06 & 53,3 & 0,29 & 10,5 \\
\hline Green manure & 2,42 & 0,43 & 21,6 & 0,18 & 8,0 \\
\hline experiment & 0,29 & & & & \\
\hline fertilizers & 0,17 & & & & \\
\hline inoculation and interaction & 0,14 & & & & \\
\hline
\end{tabular}

*) including interaction with biological preparation 
Rhizohumin was shown to be an important factor influencing crop productivity. Efficacy of biological preparation was observed in all versions, but most of the yield increases from inoculation were detected in the variants with the lowest and average dose of fertilizers. Effect of Rhizohumin on those backgrounds was equivalent to the impact of fertilizer in dose not less than $\mathrm{N}_{30} \mathrm{P}_{30} \mathrm{~K}_{30}$. It should be noted, that in those variants the highest indices of nitrous oxide losses reduction were observed, which confirms the hypothesis of additional nitrogen uptake to the constructive metabolism of plants.

Application of Rhizohumin combined with green manure and manure aftereffect was less effective, however, because of the low cost of used technologies still economically viable.

Thus, the relationship between the peculiarities of symbiotic nitrogen fixation, $\mathrm{N}_{2} \mathrm{O}$ and $\mathrm{CO}_{2}$ emissions were established. Application of microbial preparation Rhizohumin at growing of pea plants on leached black soils and low mineral backgrounds enhances the activity of nitrogen fixation and reduces the emissions of nitrous oxide. The gain of additional yield in variants with Rhizohumin was accompanied by increased binding of $\mathrm{CO}_{2}$. Hence, it was shown that pre-sowing seeds inoculation can actively influence the circulation of carbon in ecosystems. 